\title{
Small B-cell lymphomas of the spleen: how to tell them apart
}

\author{
Aliyah R. Sohani • Lawrence R. Zukerberg
}

Received: 31 May 2014 / Accepted: 3 June 2014 / Published online: 11 June 2014

(C) Springer-Verlag Berlin Heidelberg 2014

\begin{abstract}
Various subtypes of small B-cell lymphoma can involve the spleen, and their classification in splenectomy specimens may be challenging. Accurate diagnosis of these entities may be critical to ensuring appropriate treatment and prognostication. We describe the types of small B-cell lymphoma that may involve the spleen and their differential diagnosis, using splenic compartment of involvement (white pulp vs. red pulp) as a diagnostic framework. Published literature on various lymphomas of the spleen, with an emphasis on recently recognized entities and emerging molecular genetic data, is reviewed. A multifaceted approach to diagnosis, using clinical and laboratory data, morphology, immunophenotype, and molecular genetic testing, is discussed. Although relatively few small B-cell lymphoma entities involve the spleen primarily, many systemic lymphomas may involve the spleen secondarily, and some recently described entities are encountered with relative infrequency. Fortunately, an understanding of the unique anatomy of the spleen as reflected by its unusual diversity of functions, in concert with a multiparameter approach to diagnosis, can help in narrowing this broad differential diagnosis considerably, in order to reach a specific diagnosis with certainty.
\end{abstract}

Keywords Spleen $\cdot$ Lymphoma $\cdot$ Splenic marginal zone lymphoma $\cdot$ Hairy cell leukemia $\cdot$ Flow cytometry $\cdot$ Molecular diagnostics

\footnotetext{
A. R. Sohani $\cdot$ L. R. Zukerberg

James Homer Wright Pathology Laboratories of the Massachusetts General Hospital and Department of Pathology, Harvard Medical School, Boston, MA, USA

A. R. Sohani $(\bowtie)$

Department of Pathology, Massachusetts General Hospital, 55 Fruit

St., WRN 219, Boston, MA 02114, USA

e-mail: arsohani@partners.org
}

\section{Introduction}

Various types of low-grade B-cell neoplasms composed mostly of small B cells can involve the spleen and their accurate diagnosis and classification in splenectomy specimens may be challenging. In addition, many systemic lymphomas may involve the spleen secondarily, either at presentation or at the time of disease progression. Many such secondary small B-cell lymphomas have morphologic features that overlap with primary splenic marginal zone lymphoma. In some cases, higher-grade lymphomas with more aggressive clinical behavior may have cytologic or architectural features that mimic low-grade lymphomas in splenectomy specimens. In addition, reactive hyperplasia of the spleen may lead to splenomegaly, raising the differential diagnosis of lymphoma. Establishing a precise diagnosis of lymphoma in a splenectomy specimen therefore requires a combination of morphological and immunophenotypic analysis, and correlation with clinical features, other sites of disease involvement, and in some cases, cytogenetic studies or molecular genetic studies, including fluorescence in situ hybridization analysis (FISH) to detect recurrent cytogenetic abnormalities, polymerase chain reaction (PCR) for recurrent somatic point mutations or gene rearrangement studies, or sequencing of the immunoglobulin heavy chain variable region.

The normal spleen weighs approximately 150 to $200 \mathrm{~g}$. Benign splenomegaly is common and has a variety of causes ranging from congestive splenomegaly secondary to heart failure to infectious mononucleosis. In such settings, the spleen becomes enlarged, but rarely beyond $500 \mathrm{~g}$. Spleens weighing greater than $500 \mathrm{~g}$ should be considered suspicious for lymphoma. Conversely, a diagnosis of lymphoma should only be made with confirmation of clonality in normal or slightly enlarged spleens, even if the white pulp appears expanded. Initial evaluation of splenomegaly should include clinical history and 
peripheral blood counts. Morphology is helpful in the evaluation if the enlargement is due to a red pulp process, such as congestion, or a white pulp process, which can be reactive or neoplastic. The standard way to evaluate for lymphoma is through a combination of morphology and immunophenotyping, as detailed in the sections below. Occasionally, flow cytometry may not detect a B-cell clone despite worrisome morphologic features. In such cases, PCR for IGH gene rearrangement studies and FISH for recurrent cytogenetic abnormalities may be extremely useful in establishing a diagnosis of lymphoma.

Small B-cell neoplasms that commonly involve the spleen can be broadly divided into the anatomic compartment of the spleen that is predominantly involved, and this is a very helpful starting point in their differential diagnosis (Table 1). Splenic marginal zone lymphoma (SMZL) and chronic lymphocytic leukemia/small lymphocytic lymphoma (CLL/SLL) involve the white pulp predominantly, but both typically also show some degree of red pulp involvement, which is often significant in CLL. Follicular lymphoma and mantle cell lymphoma typically exhibit disease that is fairly restricted to the white pulp. In contrast, hairy cell leukemia (HCL) and lymphoplasmacytic leukemia (Waldenström's macroglobulinemia) exhibit predominantly red pulp disease, as do the provisional entities that fall into the category of unclassifiable splenic B-cell lymphoma/leukemias recognized in the most recent World Health Organization (WHO) Classification [1]. An additional important feature that may help to narrow the differential diagnosis includes a prior history of lymphoma, and if such a history exists, the knowledge of specific sites of involvement, including lymph nodes, bone marrow, peripheral blood, or other extranodal or extramedullary tissues. In particular, examination of a peripheral blood smear and peripheral blood flow cytometry can serve as helpful and important adjuncts to the diagnosis of splenic lymphoma in many instances. The diagnosis and differential diagnosis of various entities discussed in this review are summarized in Table 2.

\section{Splenic marginal zone lymphoma}

\section{Clinical features}

SMZL is a rare, indolent B-cell lymphoma subtype with a striking propensity for involvement of the spleen and splenic hilar lymph nodes. Bone marrow and peripheral blood are also commonly involved; however, involvement of peripheral lymph nodes or other extranodal sites is rare. It affects middle-aged to older adults, typically in the 6 th or 7 th decades, with a slight female predominance $[2,3]$. Patients usually present with splenomegaly, which may be massive, anemia with or without other cytopenias, and moderate lymphocytosis with circulating villous lymphocytes $[2,4,5]$. An IgM paraprotein may be present, but is smaller than that typically seen in Waldenström's macroglobulinemia, and consequent symptoms of hyperviscosity are rare [2]. Patients commonly exhibit autoimmune phenomena, particularly autoimmune hemolytic anemia, which may reflect a direct autoimmune effect of the IgM paraprotein elaborated by the lymphoma [6]. An increased seroprevalence of hepatitis $\mathrm{C}$ virus (HCV) infection is seen in patients with SMZL, and patients living in malaria endemic regions of West Africa are reported to have a relatively high incidence of SMZL [7-9]. In the latter instances, the lymphoma shares certain clinical and laboratory features with hyperreactive malarial splenomegaly due to repeated malaria infections, and may be related to emergence of a B-cell clone in the setting of parasite-induced chronic antigenic stimulation. Splenectomy is the mainstay of treatment, typically producing sustained partial responses with resolution of cytopenias, paraproteinemia and B symptoms and median overall survivals ranging from 9 to 13 years $[2,5$, 10]. For refractory cases, additional treatment options include splenic irradiation, combination chemotherapy, and monoclonal antibody therapy with rituximab [11, 12]. Treatment with interferon and ribavirin would be expected to produce a response in $\mathrm{HCV}$-positive patients $[8,9]$.

Table 1 Differential diagnosis of small B-cell lymphomas of the spleen based on anatomic compartment of involvement

\begin{tabular}{|c|c|}
\hline Predominantly white pulp disease & Predominantly red pulp disease \\
\hline Splenic marginal zone lymphoma ${ }^{a}$ & Hairy cell leukemia \\
\hline Chronic lymphocytic leukemia/small lymphocytic lymphoma $^{a}$ & Lymphoplasmacytic lymphoma (Waldenström's macroglobulinemia) \\
\hline $\begin{array}{l}\text { Follicular lymphoma } \\
\text { Mantle cell lymphoma }\end{array}$ & $\begin{array}{l}\text { Splenic small B-cell lymphoma/leukemia, unclassifiable } \\
\text { - Hairy cell leukemia variant } \\
\text { - Splenic diffuse red pulp small B-cell lymphoma }\end{array}$ \\
\hline
\end{tabular}

\footnotetext{
${ }^{a}$ Most cases of splenic marginal zone lymphoma show some degree of red pulp involvement, and significant red pulp disease is seen in the majority of cases of chronic lymphocytic leukemia/small lymphocytic lymphoma
} 


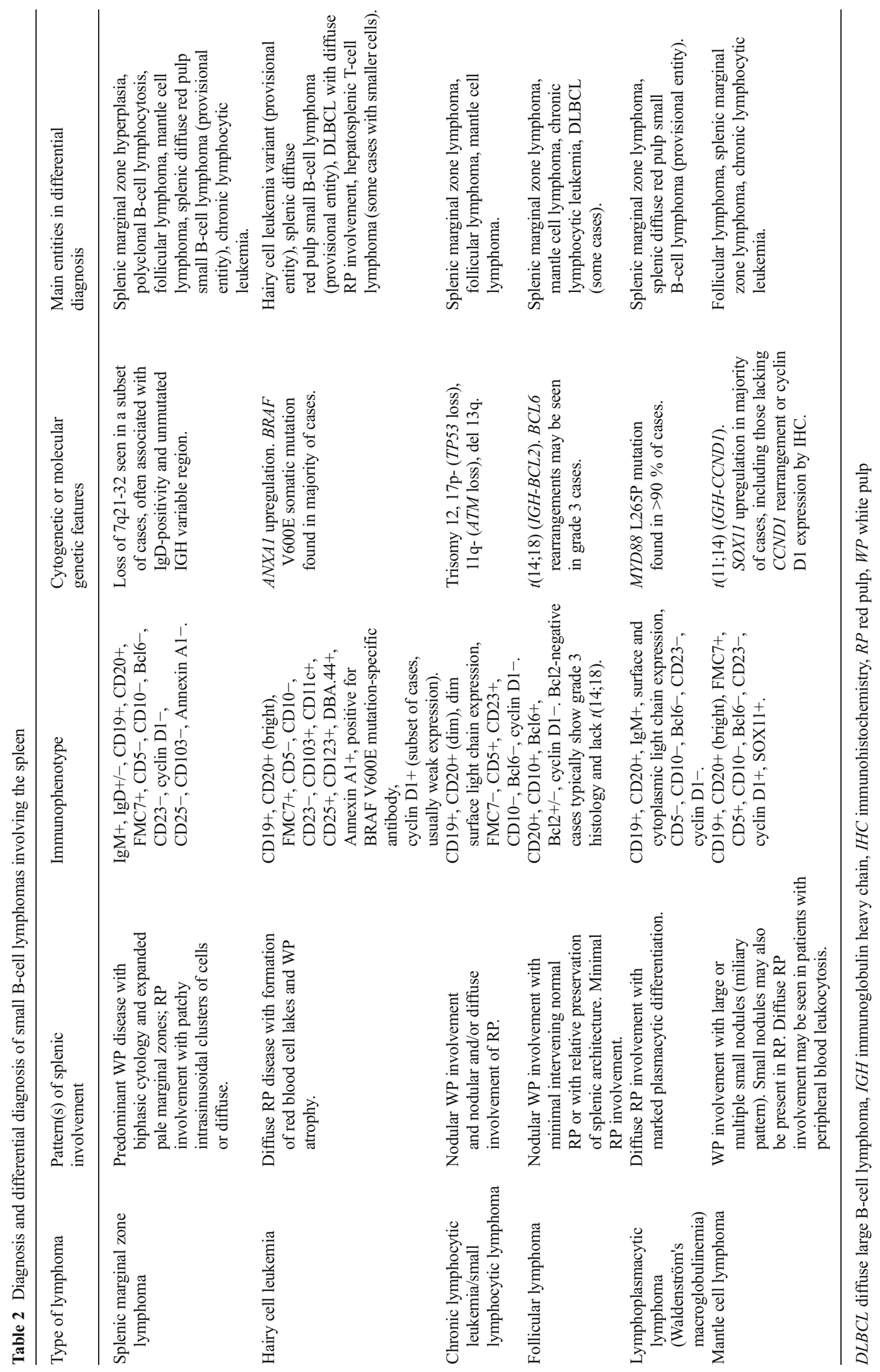


Pathologic features

The spleen is massively enlarged (median weight, 1,360 g) and gross examination of the cut surface shows a uniform multimicronodular pattern, with tiny nodules each measuring up to $0.5 \mathrm{~cm}$ dispersed throughout the splenic parenchyma; mass lesions are absent (Fig. 1a) [3]. Microscopically, white pulp follicles are characteristically expanded to about twice or more their normal size. The reactive germinal centers of the white pulp are reduced in size or completely replaced by a population of small lymphocytes with irregular nuclei, condensed chromatin and scant cytoplasm, resembling mantle zone cells, surrounded by a broad concentric zone of medium-sized cells with abundant pale cytoplasm, resembling marginal zone B cells (Fig. 1b, c) [13, 14]. Occasional large transformed cells may be present in the nodules, but increased numbers or sheets of large cells may indicate early transformation to diffuse large B-cell lymphoma. The concentric growth pattern of splenic marginal zone lymphoma, with expansion of the pale marginal zones of the splenic white pulp, is the characteristic feature from which this lymphoma derives its name. However, in our experience, recognizing the biphasic cytology may be difficult in some cases, as the marginal zone accentuation may be subtle and instead, many of the nodules are comprised of a more uniform population of small lymphocytes with moderate pale cytoplasm. Some cases may demonstrate plasmacytic differentiation, typically seen in the marginal zone component at the periphery of the nodules. In a minority of cases, reactive germinal centers at the centers of the expanded nodules are well-preserved, yielding a targetoid appearance of the white pulp nodules (Fig. 1c). Red pulp infiltration is invariably present, typically characterized by small clusters of lymphocytes present in a patchy intrasinusoidal distribution (Fig. 1d, e). Occasionally, red pulp involvement may be diffuse without formation of small nodules, and rarely, the red pulp may be involved in a diffuse pattern to such an extent as to obscure the nodular white pulp component that may be apparent only upon immunohistochemical staining with B-cell antigens, follicular dendritic cell markers, or Ki-67 [13]. Splenic hilar lymph nodes are enlarged and show partial effacement by an infiltrate of lymphocytes similar to those seen in the spleen; sinuses are typically patent [13]. If available, evaluation of a peripheral blood smear may be helpful in identifying circulating villous lymphocytes, which are typically mildly enlarged with slightly open chromatin in comparison to normal small lymphocytes,
Fig. 1 The cut surface of a spleen involved by splenic marginal zone lymphoma shows innumerable expanded white pulp nodules, yielding a multimicronodular pattern on gross examination (a)

Microscopically, the expanded white pulp nodules demonstrate complete (b, H\&E, x200) or partial (c, H\&E, x400) loss of the reactive germinal center, with surrounding zones of mantle zone type and marginal zone B cells; marginal zone expansion is particularly pronounced in panel c. Red pulp involvement is typically present in the form of small lymphoid clusters within sinuses (d, H\&E, x200), highlighted by CD20 staining (e, x200). Ki-67 stain yields an intermediate proliferation index within the white pulp nodules, reflecting the admixture of lymphoma cells with residual germinal center B cells (f, x200)
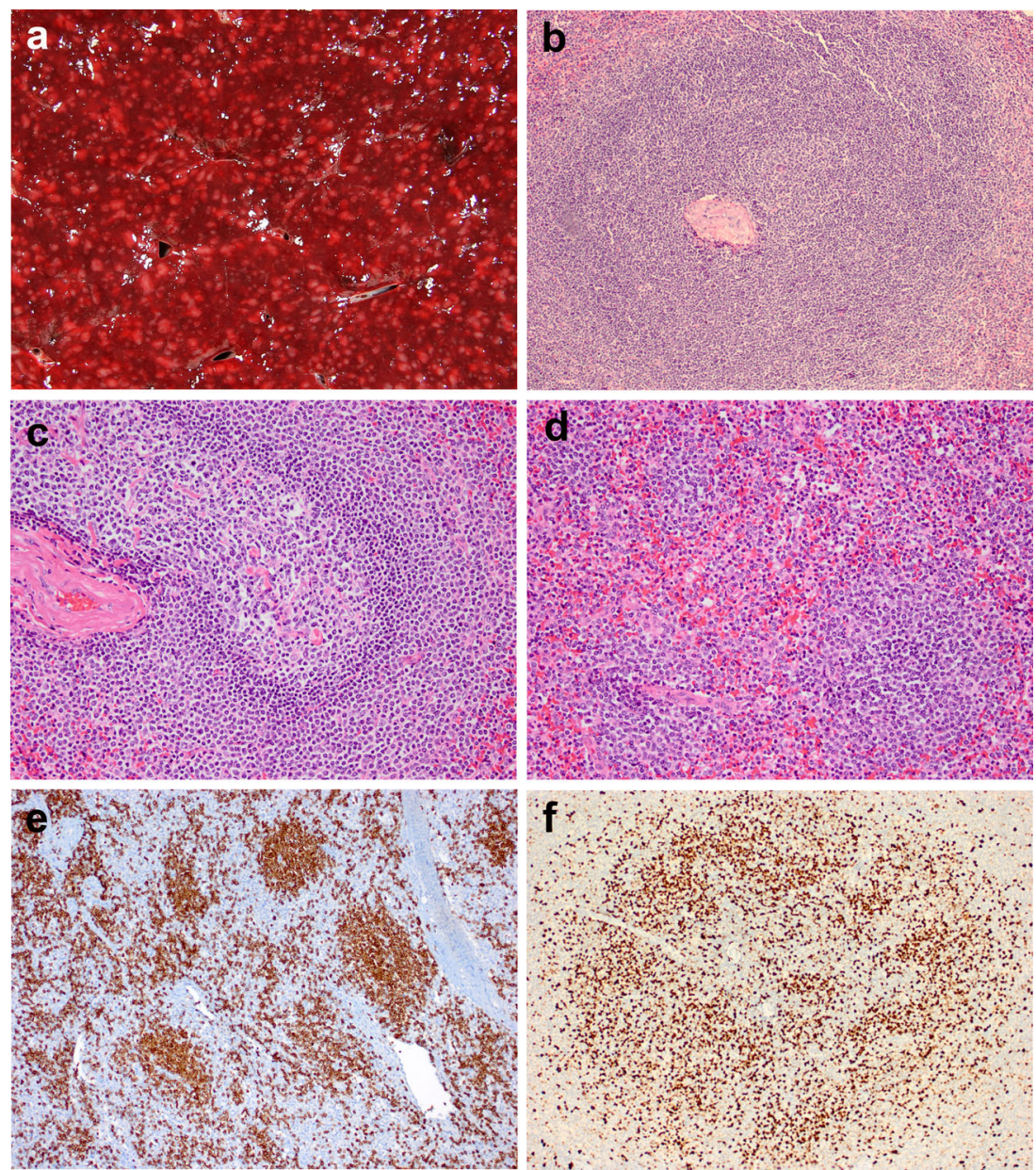
with small nucleoli and moderately abundant pale basophilic cytoplasm with non-circumferential cytoplasmic projections or blebs.

The lymphoma cells express mature B-cell markers (CD20, CD79a, Pax5) and IgM. IgD is expressed by a subset of cases. Clonal surface light chain is expressed and light chain restriction can most easily be demonstrated by flow cytometry, but can often be shown in the cytoplasm of neoplastic cells on tissue sections by immunohistochemistry or in situ hybridization. SMZL is typically negative for CD5, CD10, CD23, CD25, CD43, and CD103, and cyclin D1 is not expressed. Lymphoma cells are positive for $\mathrm{Bcl} 2$ and negative for $\mathrm{Bcl} 6$, while residual small germinal centers, if present, will show the opposite pattern of staining for these two antibodies. Staining with $\mathrm{Ki}-67$ is purported to show a distinctive annular pattern of staining, with a low proliferation fraction within the neoplastic cells, while preserved reactive follicles at the centers of the nodules exhibit a high proportion of positive nuclei. In many cases, however, the admixture of various cell types within the expanded white pulp follicles tends to yield a nodular pattern of staining with an intermediate proliferation index within the nodules (Fig. 1f). Staining for follicular dendritic cell antigens (CD21, CD23) may show a dense meshwork at the centers of the white pulp nodules with expansion or fraying at the edges, as well as focal staining within the small red pulp nodules $[13,15]$.

Historically, a post-germinal center B cell of marginal zone derivation is postulated to be the cell of origin underlying SMZL. However, more recent studies suggest that this lymphoma has greater heterogeneity in terms of its cell of origin, immunophenotype, and genetics than previously inferred, and such features may be prognostically relevant [15-17]. Similar to cases of CLL, up to one half of cases of SMZL have unmutated immunoglobulin heavy chain variable regions. These cases often show allelic loss of 7q21-32, the most common cytogenetic abnormality seen in splenic marginal zone lymphoma, and patients tend to have a more aggressive clinical course. In contrast, cases with mutated immunoglobulin heavy chain variable regions often have normal cytogenetics, are negative for IgD, and have a more favorable clinical course. Mutational analysis of the immunoglobulin heavy chain variable region requires direct sequencing of the gene segment of interest and is typically performed in a reference lab setting. However, these studies suggest that the combination of IgD expression by immunohistochemistry and FISH for $7 \mathrm{q}$ loss as a surrogate for somatic hypermutation status may be used to help predict prognosis.

\section{Differential diagnosis}

The distinct yet non-specific immunophenotype of SMZL necessitates that the diagnosis be made only after exclusion of other small B-cell lymphomas that may secondarily involve the spleen; these are discussed in the following section. Other differential diagnostic entities that are important to exclude are two reactive conditions that may mimic SMZL morphologically: splenic marginal zone hyperplasia and polyclonal B-cell lymphocytosis with progressive splenomegaly. In the cases of splenic marginal zone hyperplasia, splenomegaly is absent or mild, white pulp nodules are only minimally expanded with accentuation of the marginal zone regions (a form of reactive hyperplasia characteristic of the splenic white pulp), and the red pulp sinusoids lack small lymphoid clusters. Flow cytometry and stains for immunoglobulin light chains confirm the polytypic nature of the lymphocytes. Polyclonal B-cell lymphocytosis is an unusual chronic expansion of peripheral blood polyclonal B cells associated with progressive splenomegaly, which may be massive in some cases. Patients are typically adult female smokers of various ages. There is an association with HLA-DR7, suggesting a genetic predisposition. Patients typically have a mild lymphocytosis, elevated polyclonal serum IgM, and circulating binucleate peripheral blood lymphocytes with an activated, memory B-cell phenotype (CD20+, CD79a+, IgM+, IgD+, Bc12+, CD27+, DBA.44-, CD5-, CD10-, CD23-, Bcl6-) that are polyclonal for immunoglobulin light chains. Splenic histology has been described in relatively few cases, but is reported to resemble SMZL closely with expansion of the white pulp marginal zone areas and a biphasic growth pattern. Bone marrow biopsies demonstrate a moderate lymphoid infiltrate with interstitial and intrasinusoidal lymphocytes. Immunohistochemical stains on tissue sections characteristically show the lymphocytes to be positive for IgM and $\operatorname{IgD}$ and to express polytypic light chains. Despite the detection of various cytogenetic abnormalities in some cases, $7 \mathrm{q}$ deletions and clonal IGH gene rearrangements are not seen and progression to lymphoma has been documented in only rare cases [18]. Due to the degree of splenomegaly and the morphologic resemblance to SMZL, diagnosis requires immunophenotyping by flow cytometry of peripheral blood or bone marrow or immunohistochemical analysis of tissue to support the presence of a polyclonal B-cell population. PCR to exclude a clonal IGH gene rearrangement may be used to further support the diagnosis.

\section{Secondary splenic small B-cell lymphomas with predominantly white pulp disease}

Chronic lymphocytic leukemia/small lymphocytic lymphoma

Patients with chronic lymphocytic leukemia (CLL) frequently have splenic involvement. This may be related in part to the expression of cell surface adhesion molecules on neoplastic B cells that allow preferential homing to the spleen over other lymphoid organs $[19,20]$. Although CLL is the most common 

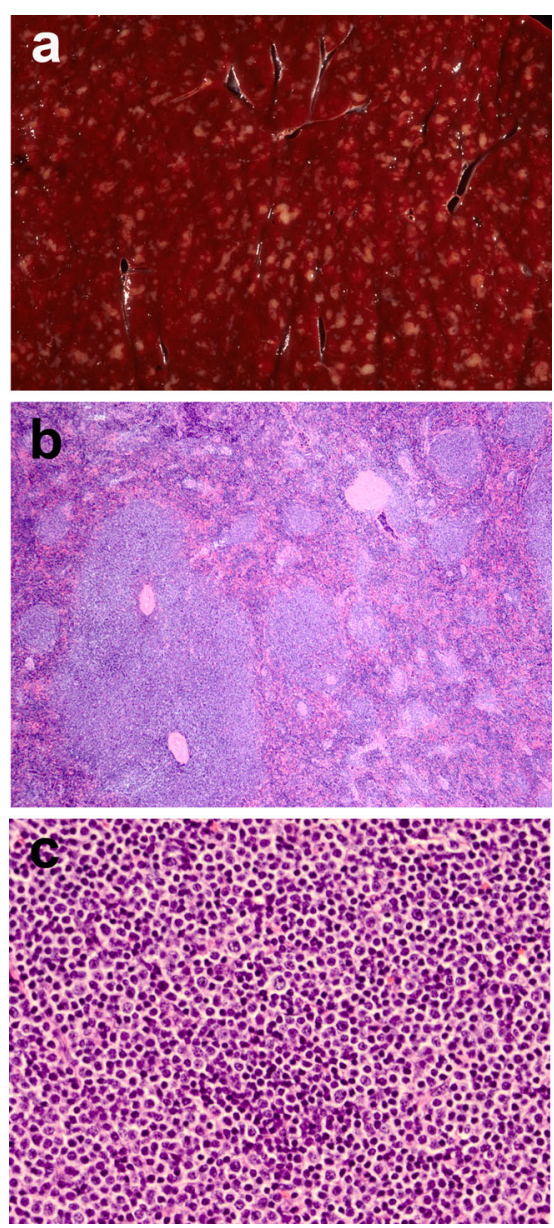

Fig. 2 The cut surface of a spleen involved by chronic lymphocytic leukemia shows variably sized and somewhat irregular expanded nodules of white pulp (a). Microscopic involvement is characterized by nodules of expanded white pulp, as well as prominent red pulp disease (b, H\&E, $\mathrm{x} 40$ ). Higher magnification shows an admixture of small lymphocytes, prolymphocytes, and few paraimmunoblasts (c, H\&E, x400)

small B-cell neoplasm to involve the spleen, the degree of splenomegaly may be less than that seen with other B-cell lymphomas [21]. The white pulp is usually prominent on gross examination, while microscopically, both white pulp and red pulp are involved (Fig. 2a, b). Expanded white pulp nodules are composed of small, mature-appearing lymphocytes with scattered admixed larger prolymphocytes and paraimmunoblasts (Fig. 2c). As in lymph nodes, the latter may coalesce to form pale-staining proliferation centers. Occasional reactive germinal centers may be present, but a marginal zone pattern mimicking SMZL is rare. Red pulp involvement, seen in the majority of cases, may be nodular, diffuse, or a mixture of the two patterns. Hilar lymph node involvement is invariably present, with partial or complete architectural effacement. Lymphoma cells exhibit the typical immunophenotype of CLL with mature B cells co-expressing CD5 and CD23, helping to distinguish this entity from SMZL, which typically lacks simultaneous expression of these two antigens. By flow cytometry, dim CD20 and surface light chain expression and absence of FMC7 help to distinguish CLL from other small B-cell neoplasms, which tend to show moderate to strong expression of these markers. Immunohistochemistry or FISH for cyclin D1 is mandatory to exclude mantle cell lymphoma. Cases of CLL frequently show characteristic abnormalities by FISH, including trisomy 12 , $\operatorname{del}(13)(\mathrm{q} 14)$, del(11)(q22-23) involving $A T M$, and/or del(17)(p13) involving TP53 [22]. While not specific for CLL, their presence may be helpful in distinguishing it from other B-cell lymphomas. Finally, correlation with complete blood count and white blood cell differential findings and peripheral blood smear morphology may be immensely helpful, as cases of CLL typically show a marked lymphocytosis exceeding that of most other small B-cell leukemic lymphomas. Circulating lymphocytes consist of small, matureappearing forms that typically lack either nucleoli or cytoplasmic projections.

\section{Follicular lymphoma}

Follicular lymphoma frequently involves the spleen secondarily and splenectomy may occasionally be the procedure leading to its initial diagnosis [23-25]. Two patterns of involvement have been identified, which occur with similar frequency (Fig. 3a). In one pattern, the spleen shows abnormal architecture with closely packed neoplastic follicles separated by minimal red pulp. Increased numbers of interfollicular B cells are present that can be detected by immunohistochemistry. In the other pattern, which has a tendency to mimic SMZL, the splenic architecture appears relatively well-preserved with only scattered neoplastic follicles. B cells may be present in red pulp, but usually only in small numbers. In both patterns, the cytology is typical of follicular lymphoma at other sites with an admixture of small cells containing irregular or convoluted nuclei (centrocytes) that predominate in low-grade cases (grade 1-2 of 3 histology), and fewer numbers of large transformed centroblasts (Fig. 3b). All cases of follicular lymphoma show strong staining for B-cell and germinal center markers (CD10 and/or Bc16); the latter feature helps in the distinction from SMZL and other small B-cell lymphomas. Bcl2 is usually overexpressed in the neoplastic follicles and correlates with a $t(14 ; 18)(\mathrm{q} 32 ; \mathrm{q} 21)$ or IGH@-BCL2 rearrangement. As seen in other sites, Bcl2 expression is weak or negative in cases of higher histological grade (i.e., grade 3 follicular lymphoma) $[25,26]$. The different patterns of splenic involvement do not appear to be associated with the presence or absence of previously diagnosed follicular lymphoma, splenic weight, or clinical stage. However, Bcl2-negative grade 3 cases are more often found to be restricted to the spleen, at least at the time of initial diagnosis. Cases with grade 3 histology may require 
staining with follicular dendritic cell markers (CD21, CD23) to uncover an underlying follicular pattern of growth, in order to distinguish them from diffuse large B-cell lymphoma. Cases with a purely follicular growth pattern with preserved red pulp may be misdiagnosed as reactive hyperplasia, but staining for $\mathrm{Bcl} 2$ can help with this differential diagnosis. The overall survival for patients with follicular lymphoma involving the spleen is about $55 \%$ at 5 years and this does not appear to depend on $\mathrm{Bcl} 2$ positivity or negativity.

\section{Mantle cell lymphoma}

Mantle cell lymphoma commonly involves the spleen, in addition to lymph nodes and other extranodal sites, such as the gastrointestinal tract, Waldeyer's ring, and peripheral blood. In some cases, splenomegaly may be prominent at the time of presentation [27, 28]. Mantle cell lymphoma often has larger macroscopic nodules than other small B-cell lymphomas involving the spleen. Grossly, the spleen is enlarged and the white pulp appears expanded and replaced by multiple fleshy nodules, or a miliary pattern of involvement may be present (Fig. 3c). Microscopically, the white pulp is expanded by small to large aggregates of lymphoma cells that exhibit characteristic cytologic features of mantle cell lymphoma seen in other nodal and extranodal sites (Fig. 3d). Typically, lymphoma cells are monomorphous, small to medium-sized centrocyte-like cells with condensed nuclear chromatin and irregular nuclear contours; however, in some cases, the cells are slightly larger with more dispersed chromatin and small nucleoli resembling lymphoblasts (blastoid variant of mantle cell lymphoma). The nodules may contain scattered, single epithelioid histiocytes. Residual germinal centers are typically absent, but in some cases, a mantle zone growth pattern may be present or the white pulp nodules may contain marginal zones, mimicking splenic marginal zone lymphoma. Other cases may show small nodules of lymphoma cells in the red pulp, or diffuse red pulp involvement can occur in rare cases with a peripheral blood leukocytosis [27]. Splenic lymph nodes are almost always involved. The differential diagnosis includes SMZL, as well as other small B-cell lymphomas, but immunohistochemical stains for CD5 and especially for cyclin D1, can usually readily distinguish mantle cell lymphoma from other small B-cell neoplasms. Rare cases of mantle cell lymphoma that lack a cyclin D1 gene rearrangement and cyclin D1 expression by immunohistochemistry have been reported: these cases, otherwise, share the morphology, immunophenotype, and gene expression profile of cyclin D1-positive mantle cell lymphoma, including overexpression of the SOX11 transcription factor. SOX11 immunohistochemistry is, therefore, emerging as an important tool in identifying such cases of cyclin D1-negative mantle cell lymphoma [29-31].

\section{Hairy cell leukemia}

\section{Clinical features}

Hairy cell leukemia (HCL), a rare, chronic, mature small Bcell leukemic lymphoma that involves the bone marrow, spleen, and peripheral blood, derives its name derives from the characteristic morphology of leukemic cells containing delicate, hair-like, circumferential cytoplasmic projections, best seen on bone marrow aspirate and peripheral blood smears. The median age of presentation is $45-50$ years, and there is a striking male predominance (male-to-female ratio, 4-5:1). Unlike other B-cell leukemic lymphomas, patients typically present with leukopenia or sometimes, pancytopenia, and an absolute monocytopenia is characteristic. In fact, the latter may be a clue to the diagnosis in cases in which the number of circulating neoplastic cells is small and the marrow fibrotic, making them difficult to identify on peripheral blood and bone marrow aspirate smears. While the diagnosis is typically made on bone marrow core biopsy specimens, HCL almost always involves the spleen, and splenomegaly is part of the typical clinical presentation [32, 33]. Other presenting symptoms and signs including left upper quadrant pain, constitutional symptoms, hepatomegaly, and recurrent infections. The treatment of HCL differs from that of other small B-cell leukemic lymphomas, underscoring the importance of its correct diagnosis and distinction from SMZL and other B-cell lymphomas with leukemic dissemination. In the majority of patients, a single course of the nucleoside analog, cladribine (also known as 2-chlorodeoxyadenosine, 2-CDA), given as a continuous intravenous infusion over 7 days, induces a durable complete response with resolution of splenomegaly and cytopenias [34]. Among the small proportion of patients who relapse, therapeutic options include re-treatment with cladribine or rituximab monotherapy [35].

\section{Pathologic features}

In contrast to the other small B-cell lymphomas involving the spleen discussed thus far (including SMZL), HCL preferentially involves the red pulp rather than the white pulp. Grossly, the spleen is massively enlarged (median weight, 1,200 g), and examination of the cut surface shows a beefy red pulp and absence of the normal pinpoint white pulp nodules (Fig. 4a). On microscopic examination, red pulp sinuses and cords are diffusely infiltrated by monomorphous round to oval cells with smooth nuclear contours, open chromatin, inconspicuous nucleoli, and abundant clear cytoplasm, leading to expansion 

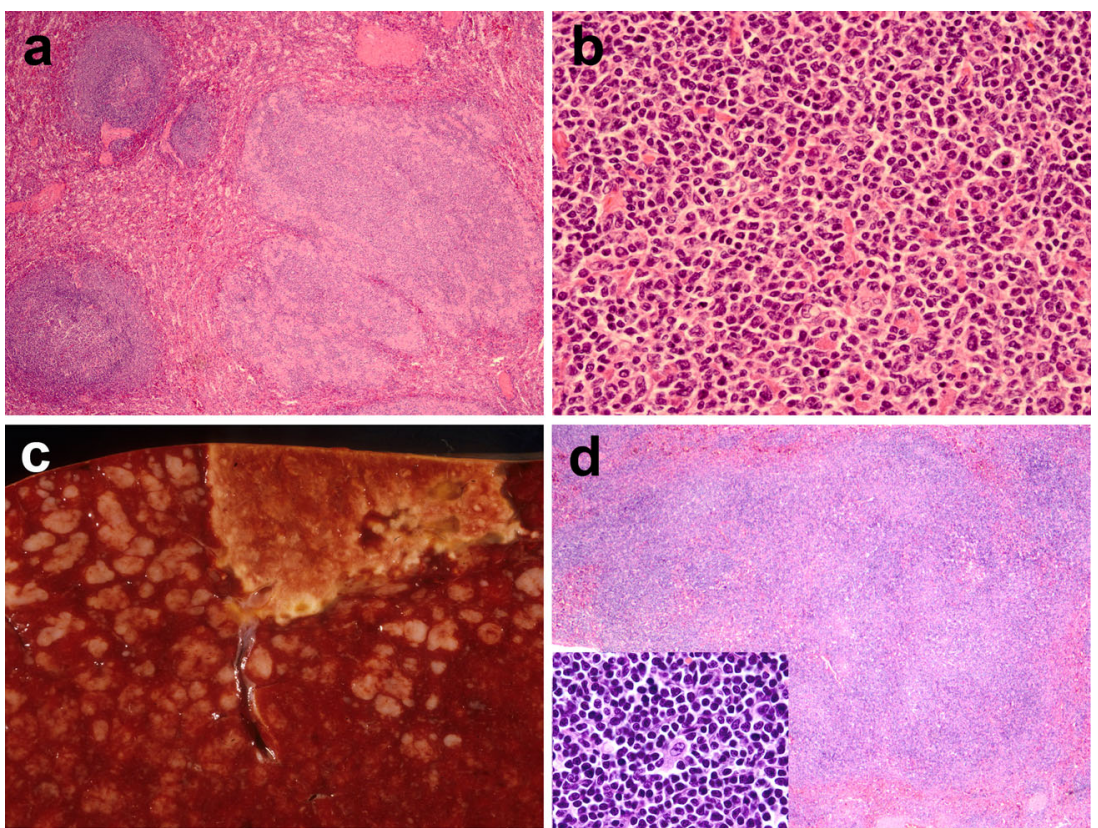

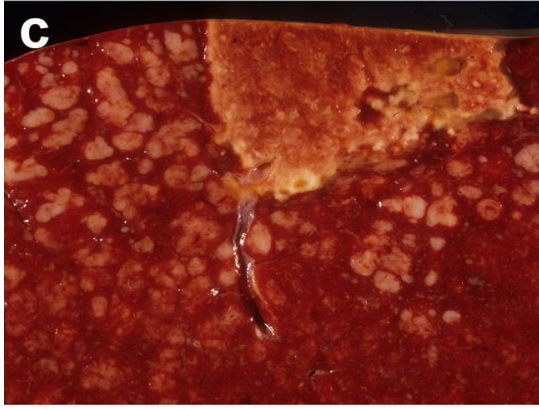

Fig. 3 A single microscopic field shows both patterns of follicular lymphoma involving the spleen: closely packed expanded follicles are seen on the right, with minimal intervening red pulp, while on the left, the splenic architecture is better preserved with more widely-spaced neoplastic follicles (a, H\&E, x40). High-power examination of neoplastic follicle centers shows a predominance of small centrocytes, consistent with grade 1-2 of 3 morphology (b, H\&E, x400). The cut surface of spleen involved

of the red pulp sinuses and secondary atrophy of the white pulp (Fig. 4b) [36]. Although not specific to HCL involving the spleen, microscopic erythrocyte-filled spaces, termed "pseudosinuses" or "red blood cell lakes," are characteristically present, which are thought to result from leukemic cell adhesion and subsequent damage to splenic sinus endothelial cells [37]. In both spleen and bone marrow, the lack of the distinct lymphoid aggregates is important in distinguishing cases of HCL from SMZL and other small B-cell neoplasms. In particular, if lymphoid aggregates are present on examination of a bone marrow biopsy (performed in the majority of cases for diagnosis and staging), the diagnosis of HCL should be reconsidered.

Immunophenotypically, the hairy cells are strongly positive for CD20, FMC7, and surface light chain, helping to distinguish it from CLL, which shows weaker staining for these antigens. While HCL is usually negative for $\mathrm{CD} 5, \mathrm{CD} 10$, and $\mathrm{CD} 23$, it characteristically express a combination of antigens not seen in SMZL, including DBA.44, CD103, CD25, CD11c, and CD123; of these, CD103 is to be the most specific for HCL, but may be expressed in cases of hairy cell leukemia variant (HCLv, see below) [38]. Flow cytometry is typically used to detect CD103 expression, but a rabbit monoclonal antibody has recently been validated for use on paraffinembedded tissue, allow for its detection in cases lacking fresh tissue for flow cytometric analysis [39]. by mantle cell lymphoma shows prominent, irregular, expanded nodules centered on the white pulp; a large subcapsular infarct is also present in this case (c). Microscopically, there is replacement of normal white pulp nodules by atypical lymphohistiocytic aggregates (d, H\&E, x200) containing monomorphous, small to medium-sized centrocyte-like cells and scattered epithelioid histiocytes on higher magnification (d inset, H\&E, $\mathrm{x} 1,000)$

Immunophenotypic variations in HCL have been reported, including expression of CD10 or CD23 in occasional cases [40, 41]. Up to $40 \%$ of cases express cyclin D1 by immunohistochemistry but lack the $t(11 ; 14)$ by cytogenetics or FISH, indicating an alternative pathway of cyclin D1 overexpression; in such cases, staining is usually weaker compared to mantle cell lymphoma [42]. Annexin A1, normally present in phagocytic cells of the myeloid lineage but absent in normal B cells, has been found to be upregulated in gene expression profiling studies of HCL. Immunocytochemical or immunohistochemical detection of the Annexin A1 protein has subsequently been shown to be highly sensitive and specific for HCL, distinguishing it from both SMZL and HCLv [43]. Finally, whole exome sequencing studies have identified somatic mutations of $B R A F$ resulting in an amino acid substitution of glutamic acid for valine at position 600 (V600E) as being highly specific for HCL and not present in other B-cell lymphomas, including those that may involve the spleen and those that closely mimic HCL morphologically and immunophenotypically [44, 45]. PCR-based assays for this point mutation are helpful in confirming the diagnosis of HCL and in monitoring for minimal residual disease and early recurrence following therapy. The development of a BRAF V600E mutationspecific antibody allows for the visual detection of cells expressing the mutant protein on tissue sections, shows 

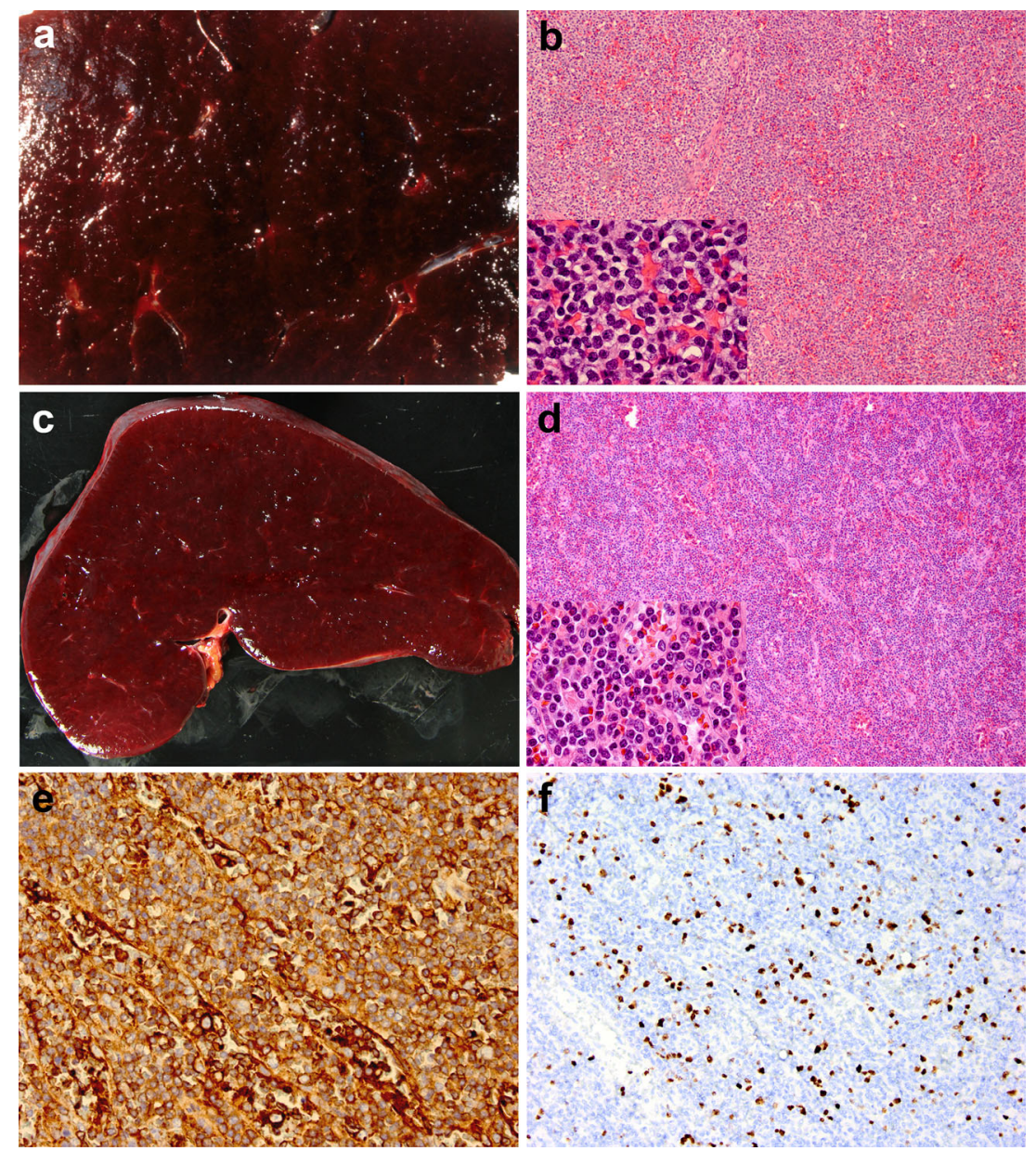

Fig. 4 In hairy cell leukemia, splenic involvement is characterized grossly by a beefy-red cut surface and absence of discernible white pulp nodules (a). Microscopically, there is diffuse infiltration of red pulp cords and sinuses, with secondary atrophy of the white pulp (b, H\&E, x200). Cytologically, hairy cells are oval or bean-shaped with smooth nuclear contours, slightly open chromatin, and abundant clear cytoplasm (b inset, $H \& E, x 400)$. The cut surface of the spleen in splenic diffuse red pulp small B-cell lymphoma shows red pulp prominence without expanded white pulp nodules, similar to the gross findings seen in hairy cell leukemia (c). Microscopically, splenic diffuse red pulp small B-cell

excellent correlation with $B R A F$ mutation status, and may be particularly useful in cases with low tumor burden [46].

\section{Other splenic lymphomas with predominantly red pulp disease}

Hairy cell leukemia variant

Despite its name, HCLv is considered a separate diagnostic entity from HCL rather than simply a morphological variant, due to several distinct clinical and pathological features. Currently categorized as a provisional entity in the 2008 WHO Classification under the umbrella of "splenic B-cell lymphoma/ lymphoma shows infiltration of both cords and sinuses by lymphoma cells (d, H\&E, x200). On high-power examination, the lymphoid cells are monomorphous and small to medium in size, with round, regular nuclei, condensed chromatin, inconspicuous nucleoli, and scant cytoplasm (d inset, $\mathrm{H} \& \mathrm{E}, \mathrm{x} 1,000)$. The neoplastic cells are positive for IgG by immunohistochemistry $(\mathbf{e}, \mathrm{x} 200)$ and $\mathrm{Ki}-67$ shows an overall low proliferation index that is homogenous throughout the section, without evidence of a nodular or annular staining pattern that would be expected in splenic marginal zone lymphoma (f, x200)

leukemia, unclassifiable," HCLv is a rare B-cell neoplasm in which the morphological features of the neoplastic lymphocytes are intermediate between those of hairy cells and prolymphocytes. Cells have moderately basophilic cytoplasm with cytoplasmic projections and round to oval nuclei; however, unlike classical HCL cells, HCLv cells contain a prominent central nucleolus. The bone marrow, peripheral blood and spleen are commonly involved, with preferential involvement for the splenic red pulp. Clinically, there is a leukocytosis instead of a leukopenia, and absence of an absolute monocytopenia [47, 48]. Importantly, HCLv shows an inadequate response to cladribine, the nucleoside analog that is effective in treating HCL. Neoplastic cells may be positive for $\mathrm{CD} 103$, but lack expression of $\mathrm{CD} 25, \mathrm{CD} 123$, and Annexin $\mathrm{A}$, and lack $B R A F$ 
Fig. 5 Splenic involvement by lymphoplasmacytic lymphoma is characterized by prominent red pulp disease (a, H\&E, x400) and conspicuous plasmacytic differentiation, evident both on histological examination (b, $\mathrm{H} \& \mathrm{E}, \mathrm{x} 1,000)$ and by in situ hybridization for kappa (c, x200) and lambda (d, x200) immunoglobulin light chains

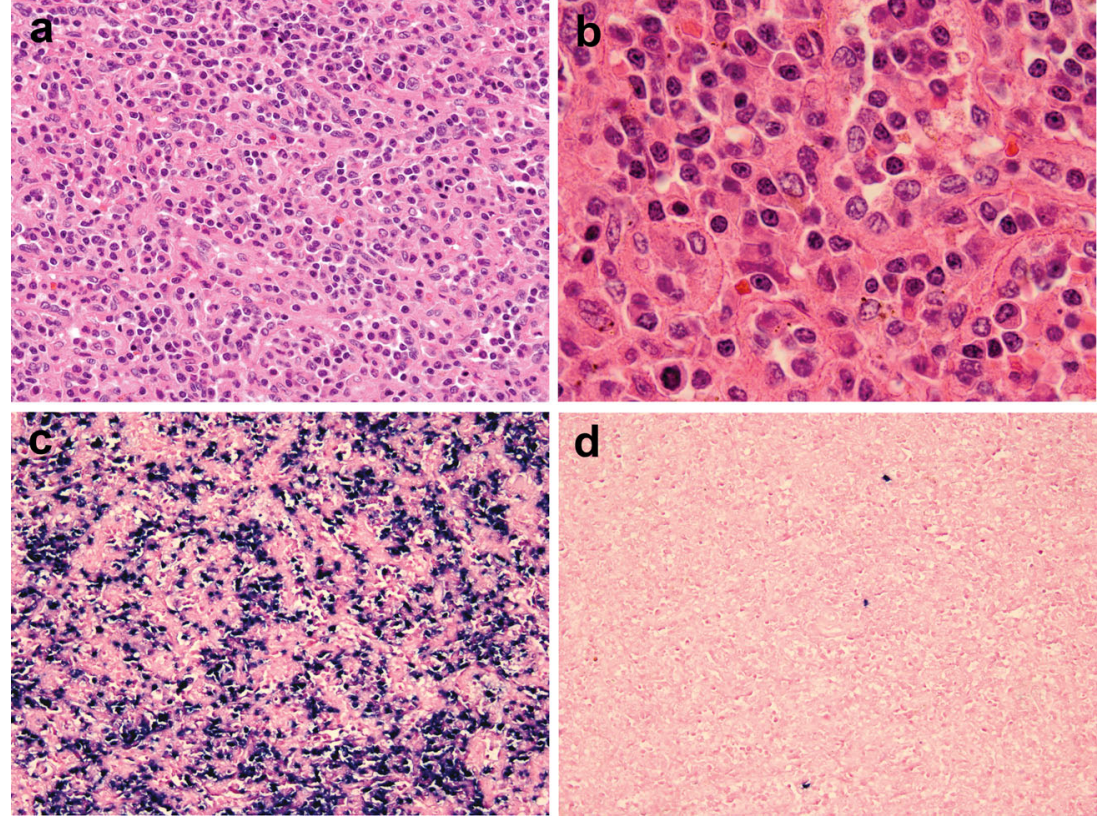

V600E mutation by PCR and BRAF V600E expression by immunohistochemistry [42-45, 49]. The precise biological relationship, if any, between $\mathrm{HCLv}$ and splenic diffuse red pulp small B-cell lymphoma (SDRPSBCL, see below) is not known. Cases that do not fulfill diagnostic criteria for the well-defined entity of HCL or the provisional entities of HCLV or SDRPSBCL are best placed in an unclassified category of splenic small B-cell lymphoma/leukemia until more is known about the pathogenetic differences underlying such neoplasms [1].

Splenic diffuse red pulp small B-cell lymphoma

Cases of SDRPSBCL share some morphologic and immunophenotypic features with SMZL, particularly on initial bone marrow and peripheral blood evaluation, but show a strikingly different pattern from SMZL on examination of splenectomy specimens, with diffuse red pulp involvement $[50,51]$. SDRPSBCL is currently recognized as a provisional entity in the 2008 WHO Classification [1]. The gross appearance is similar to that of HCL, as cases show no expanded white pulp nodules either grossly or microscopically, but rather extensive red pulp disease leading to massive splenomegaly, absence of follicles and atrophy of the white pulp, with infiltration of both the cords and sinuses by lymphoma cells (Fig. 4c, d). Neoplastic cells are monomorphous, small to medium in size with round, regular nuclei, condensed chromatin, and inconspicuous to small nucleoli with scant pale eosinophilic cytoplasm; plasmacytic differentiation is absent (Fig. 4d). In extra-splenic sites the morphology and patterns of involvement may closely resemble SMZL: hilar lymph nodes show preservation of sinuses; bone marrow shows non- paratrabecular, interstitial and intrasinusoidal lymphoid aggregates; and peripheral blood may contain circulating villous lymphocytes. The immunophenotype of the lymphoma cells is non-specific, similar to that of SMZL, with negativity for CD5, CD10, CD23, and cyclin D1. The HCL-specific markers, Annexin A1 and BRAF V600E, are also negative although some cases have been reported to be positive for CD103. Most cases described to date are positive for DBA.44 and $\operatorname{IgG}$ (Fig. 4e), a subset is positive for CD11c, and $\operatorname{IgD}$ is usually negative. Immunohistochemical staining for Ki-67 shows a uniformly low proliferation index, with absence of the typical nodular or annular staining pattern seen in SMZL (Fig. 4f). No characteristic molecular genetic features have been described to date, and cases lack both the $7 \mathrm{q}$ deletions commonly seen in SMZL and BRAF V600E mutations seen in HCL. Whether such cases represent a diffuse variant of SMZL as suggested by the shared cytology, growth pattern in certain organs, and overlapping immunophenotype versus a distinct disease entity remains to be fully elucidated.

Lymphoplasmacytic lymphoma (Waldenström's macroglobulinemia)

Lymphoplasmacytic lymphoma (LPL) is a small B-cell neoplasm with conspicuous plasmacytic differentiation and disseminated involvement of bone marrow, lymph nodes, spleen, and peripheral blood that characteristically lacks expression of CD5, $\mathrm{CD} 10$, and CD23 [52]. Cases associated with bone marrow involvement and an IgM paraprotein are known as Waldenström's macroglobulinemia. The immunophenotype and association with an IgM M-component may raise the differential diagnosis of SMZL with plasmacytic differentiation in 
splenectomy specimens. However, splenic involvement by LPL is characterized by predominant involvement of the red pulp with relative sparing of the white pulp. In addition, more conspicuous plasmacytic differentiation is usually apparent in LPL compared to SMZL, both by morphology and on immunohistochemical or in situ hybridization studies of tissue sections (Fig. 5). Clinically, patients with LPL have more extensive disease involving the bone marrow or lymph nodes, have higher degrees of IgM paraproteinemia often leading to symptoms of hyperviscosity, and the spleen is secondarily involved with a milder degree of enlargement compared with SMZL. The MYD88 L265P somatic point mutation that has been recently described in $>90 \%$ of LPL is reported to be relatively uncommon in marginal zone lymphomas, indicating its potential utility in the work-up of splenic Bcell lymphomas with plasmacytic differentiation and in supporting the diagnosis of LPL [53]. Despite the shared feature of predominant red pulp disease, distinction between LPL and HCL is usually straightforward on clinical, morphological, and immunophenotypic grounds without the need for molecular diagnostic testing.

Splenic diffuse large B-cell lymphoma with diffuse Red pulp infiltration

Diffuse red pulp infiltration is a rare pattern of involvement seen in primary splenic diffuse large B-cell lymphoma (DLBCL). In such cases, the spleen is enlarged and shows a homogeneous beefy red appearance, unlike that of typical DLBCL characterized by discrete tumor nodules containing a fish-flesh appearance on cross-section. Microscopically, there is diffuse infiltration of the red pulp and sinuses by large lymphoid cells with centroblastic, lobated, or pleomorphic cytology, without white pulp expansion or prominence. Necrosis is present in some cases and hilar lymph nodes are often involved. Distinction from low-grade splenic B-cell lymphomas with predominantly red pulp involvement is usually straightforward, given the large cell size and other highgrade morphological features, such as brisk mitotic activity, apoptosis and single cell necrosis, as well as an elevated Ki-67 proliferation index, which is usually $>75 \%[54,55]$.

\section{Hepatosplenic T-cell lymphoma}

Hepatosplenic T-cell lymphoma typically involves the spleen, liver and bone marrow, and most patients are young men with a median age of 25 years $[56,57]$. Some cases occur in the setting of immunosuppression due to prior transplantation or therapy with immunosuppressive agents for other reasons [58, 59]. Similar to SMZL, rare cases have been reported in the setting of Plasmodium falciparum malaria infection, which is associated with an expansion of $\gamma \delta$-T cells in the peripheral blood and spleen [60]. Patients present with abdominal pain and often have fever, night sweats, or weight loss. The spleen and liver are diffusely, often strikingly enlarged, without conspicuous peripheral lymphadenopathy. Patients may have peripheral blood cytopenias, including anemia and thrombocytopenia. The disease is chemotherapy-responsive initially, but in general progresses in an aggressive manner with a median survival of less than one year.

Neoplastic cells preferentially involve splenic red pulp and are typically medium-sized or occasionally large with oval nuclei, fine chromatin and abundant pale cytoplasm [61]. Unusual cases with small to medium-sized cells may lead to diagnostic confusion with splenic B-cell lymphomas with diffuse red pulp involvement. However, immunohistochemical analysis readily identifies a cytotoxic T-cell immunophenotype (CD2+, CD3+, CD5-/+, CD4-, CD8-/+, CD 7+/-, TIA-1+). In addition, prominent erythrophagocytosis in the spleen, present in many cases, may be a clue to the diagnosis. Molecular genetic analysis shows clonal T-cell receptor gene rearrangements and the most common cytogenetic abnormalities are isochromosome $7 \mathrm{q}$ and trisomy 8 [59].

\section{Conclusion}

Although a limited number of small B-cell lymphomas involve the spleen primarily, their differential diagnosis includes a wider array of lymphoid neoplasms that may involve the spleen secondarily, as well as more recently defined entities that are encountered with only rare frequency. Fortunately, an understanding of the anatomic compartments of the spleen, in concert with a multiparameter approach to diagnosis utilizing clinical and laboratory data, morphology, immunophenotyping, and molecular genetic testing, can help to narrow this broad differential diagnosis considerably, as accurate diagnosis of the specific type of lymphoma present in the spleen is often critical to appropriate treatment and prognostication.

Conflicts of interest The authors declare that they have no conflict of interest.

Disclosures The authors have no conflicts of interest to disclose.

Funding sources None.

\section{References}

1. Piris MA, Foucar K, Mollejo M, Campo E, Falini B (2008) Splenic B-cell lymphoma/leukemia, unclassifiable. In: Swerdlow SH, Campo E, Harris NL, Jaffe ES, Pileri SA, Stein H, Thiele J, Vardiman JW (eds) WHO Classification of Tumours of the Haematopoietic and Lymphoid Tissues, 4th edn. IARC, Lyon, pp 191-193 
2. Berger F, Felman P, Thieblemont C, Pradier T, Baseggio L, Bryon PA, Salles G, Callet-Bauchu E, Coiffier B (2000) Non-MALT marginal zone B-cell lymphomas: a description of clinical presentation and outcome in 124 patients. Blood 95:1950-1956

3. Diebold J, Le Tourneau A, Comperat E, Molina T, Audouin J (2005) Primary splenic and nodal marginal zone lymphoma. J Clin Exp Hematopathol 45:1-14

4. Dogan A, Isaacson PG (2003) Splenic marginal zone lymphoma. Semin Diagn Pathol 20:121-127

5. Thieblemont C, Felman P, Callet-Bauchu E, Traverse-Glehen A, Salles G, Berger F, Coiffier B (2003) Splenic marginal-zone lymphoma: a distinct clinical and pathological entity. Lancet Oncol 4:95-103

6. Ziakas PD, Giannouli S, Tasidou A, Skopouli FN, Voulgarelis M (2006) Multiple autoimmune phenomena in splenic marginal zone lymphoma. Leuk Lymphoma 47:772-775

7. Bates I, Bedu-Addo G, Rutherford T, Bevan DH (1992) Splenic lymphoma with villous lymphocytes in tropical West Africa. Lancet 340:575-577

8. De Renzo A, Perna F, Persico M, Notaro R, Mainolfi C, de Sio I, Ciancia G, Picardi M, Del Vecchio L, Pane F, Rotoli B (2008) Excellent prognosis and prevalence of $\mathrm{HCV}$ infection of primary hepatic and splenic non-Hodgkin's lymphoma. Eur J Haematol 81: $51-57$

9. Saadoun D, Suarez F, Lefrere F, Valensi F, Mariette X, Aouba A, Besson C, Varet B, Troussard X, Cacoub P, Hermine O (2005) Splenic lymphoma with villous lymphocytes, associated with type II cryoglobulinemia and HCV infection: a new entity? Blood 105:74-76

10. Oscier D, Owen R, Johnson S (2005) Splenic marginal zone lymphoma. Blood Rev 19:39-51

11. Abramson JS, Chatterji M, Rahemtullah A (2008) Case records of the Massachusetts General Hospital. Case 39-2008. A 51-year-old woman with splenomegaly and anemia. N Engl J Med 359:2707-2718

12. Kalpadakis C, Pangalis GA, Dimopoulou MN, Vassilakopoulos TP, Kyrtsonis MC, Korkolopoulou P, Kontopidou FN, Siakantaris MP, Dimitriadou EM, Kokoris SI, Tsaftaridis P, Plata E, Angelopoulou MK (2007) Rituximab monotherapy is highly effective in splenic marginal zone lymphoma. Hematol Oncol 25:127-131

13. Isaacson PG, Matutes E, Burke M, Catovsky D (1994) The histopathology of splenic lymphoma with villous lymphocytes. Blood 84: 3828-3834

14. Van Huyen JP, Molina T, Delmer A, Audouin J, Le Tourneau A, Zittoun R, Bernadou A, Diebold J (2000) Splenic marginal zone lymphoma with or without plasmacytic differentiation. Am J Surg Pathol 24:1581-1592

15. Papadaki T, Stamatopoulos K, Belessi C, Pouliou E, Parasi A, Douka V, Laoutaris N, Fassas A, Anagnostopoulos A, Anagnostou D (2007) Splenic marginal-zone lymphoma: one or more entities? A histologic, immunohistochemical, and molecular study of 42 cases. Am J Surg Pathol 31:438-446

16. Algara P, Mateo MS, Sanchez-Beato M, Mollejo M, Navas IC, Romero L, Sole F, Salido M, Florensa L, Martinez P, Campo E, Piris MA (2002) Analysis of the $\operatorname{IgV}(\mathrm{H})$ somatic mutations in splenic marginal zone lymphoma defines a group of unmutated cases with frequent 7q deletion and adverse clinical course. Blood 99:1299 1304

17. Stamatopoulos K, Belessi C, Papadaki T, Kalagiakou E, Stavroyianni N, Douka V, Afendaki S, Saloum R, Parasi A, Anagnostou D, Laoutaris N, Fassas A, Anagnostopoulos A (2004) Immunoglobulin heavy- and light-chain repertoire in splenic marginal zone lymphoma. Mol Med 10:89-95

18. Del Giudice I, Pileri SA, Rossi M, Sabattini E, Campidelli C, Starza ID, De Propris MS, Mancini F, Perrone MP, Gesuiti P, Armiento D, Quattrocchi L, Tafuri A, Amendola A, Mauro FR, Guarini A, Foa R (2009) Histopathological and molecular features of persistent polyclonal B-cell lymphocytosis (PPBL) with progressive splenomegaly. Br J Haematol 144:726-731
19. Bairey O, Zimra Y, Rabizadeh E, Shaklai M (2004) Expression of adhesion molecules on leukemic B cells from chronic lymphocytic leukemia patients with predominantly splenic manifestations. Isr Med Assoc J 6:147-151

20. Hartmann TN, Grabovsky V, Wang W, Desch P, Rubenzer G, Wollner S, Binsky I, Vallon-Eberhard A, Sapoznikov A, Burger M, Shachar I, Haran M, Honczarenko M, Greil R, Alon R (2009) Circulating B-cell chronic lymphocytic leukemia cells display impaired migration to lymph nodes and bone marrow. Cancer Res 69: 3121-3130

21. Arber DA, Rappaport H, Weiss LM (1997) Non-Hodgkin's lymphoproliferative disorders involving the spleen. Mod Pathol 10:18-32

22. Dohner H, Stilgenbauer S, Benner A, Leupolt E, Krober A, Bullinger L, Dohner K, Bentz M, Lichter P (2000) Genomic aberrations and survival in chronic lymphocytic leukemia. N Engl J Med 343:1910-1916

23. Bende RJ, Smit LA, van Noesel CJ (2007) Molecular pathways in follicular lymphoma. Leukemia 21:18-29

24. Gandhi MK, Marcus RE (2005) Follicular lymphoma: time for a rethink? Blood Rev 19:165-178

25. Howard MT, Dufresne S, Swerdlow SH, Cook JR (2009) Follicular lymphoma of the spleen: multiparameter analysis of 16 cases. Am J Clin Pathol 131:656-662

26. Mollejo M, Rodriguez-Pinilla MS, Montes-Moreno S, Algara P, Dogan A, Cigudosa JC, Juarez R, Flores T, Forteza J, Arribas A, Piris MA (2009) Splenic follicular lymphoma: clinicopathologic characteristics of a series of 32 cases. Am J Surg Pathol 33:730-738

27. Kansal R, Ross CW, Singleton TP, Finn WG, Schnitzer B (2003) Histopathologic features of splenic small B-cell lymphomas. A study of 42 cases with a definitive diagnosis by the World Health Organization classification. Am J Clin Pathol 120:335-347

28. Pittaluga S, Verhoef G, Criel A, Wlodarska I, Dierlamm J, Mecucci C, Van den Berghe H, De Wolf-Peeters C (1996) "Small” B-cell nonHodgkin's lymphomas with splenomegaly at presentation are either mantle cell lymphoma or marginal zone cell lymphoma. A study based on histology, cytology, immunohistochemistry, and cytogenetic analysis. Am J Surg Pathol 20:211-223

29. Fu K, Weisenburger DD, Greiner TC, Dave S, Wright G, Rosenwald A, Chiorazzi M, Iqbal J, Gesk S, Siebert R, De Jong D, Jaffe ES, Wilson WH, Delabie J, Ott G, Dave BJ, Sanger WG, Smith LM, Rimsza L, Braziel RM, Muller-Hermelink HK, Campo E, Gascoyne RD, Staudt LM, Chan WC (2005) Cyclin D1-negative mantle cell lymphoma: a clinicopathologic study based on gene expression profiling. Blood 106:4315-4321

30. Mozos A, Royo C, Hartmann E, De Jong D, Baro C, Valera A, Fu K, Weisenburger DD, Delabie J, Chuang SS, Jaffe ES, Ruiz-Marcellan C, Dave S, Rimsza L, Braziel R, Gascoyne RD, Sole F, LopezGuillermo A, Colomer D, Staudt LM, Rosenwald A, Ott G, Jares P, Campo E (2009) SOX11 expression is highly specific for mantle cell lymphoma and identifies the cyclin D1-negative subtype. Haematologica 94:1555-1562

31. Soldini D, Valera A, Sole C, Palomero J, Amador V, Martin-Subero JI, Ribera-Cortada I, Royo C, Salaverria I, Bea S, Gonzalvo E, Johannesson H, Herrera M, Colomo L, Martinez A, Campo E (2014) Assessment of SOX11 expression in routine lymphoma tissue sections: characterization of new monoclonal antibodies for diagnosis of mantle cell lymphoma. Am J Surg Pathol 38:86-93

32. Cannon T, Mobarek D, Wegge J, Tabbara IA (2008) Hairy cell leukemia: current concepts. Cancer Invest 26:860-865

33. Fanta PT, Saven A (2008) Hairy cell leukemia. Cancer Treat Res 142: 193-209

34. Tallman MS, Hakimian D, Rademaker AW, Zanzig C, Wollins E, Rose E, Peterson LC (1996) Relapse of hairy cell leukemia after 2chlorodeoxyadenosine: long-term follow-up of the Northwestern University experience. Blood 88:1954-1959

35. Angelopoulou MK, Pangalis GA, Sachanas S, Kokoris SI, Anargyrou K, Galani Z, Kalpadakis C, Vassilakopoulos TP (2008) 
Outcome and toxicity in relapsed hairy cell leukemia patients treated with rituximab. Leuk Lymphoma 49:1817-1820

36. Burke JS, Byrne GE Jr, Rappaport H (1974) Hairy cell leukemia (leukemic reticuloendotheliosis). I. A clinical pathologic study of 21 patients. Cancer 33:1399-1410

37. Pilon VA, Davey FR, Gordon GB, Jones DB (1982) Splenic alterations in hairy-cell leukemia: II. an electron microscopic study. Cancer 49:1617-1623

38. Del Giudice I, Matutes E, Morilla R, Morilla A, Owusu-Ankomah K, Rafiq F, A'Hern R, Delgado J, Bazerbashi MB, Catovsky D (2004) The diagnostic value of CD123 in B-cell disorders with hairy or villous lymphocytes. Haematologica 89:303-308

39. Morgan EA, Yu H, Pinkus JL, Pinkus GS (2013) Immunohistochemical detection of hairy cell leukemia in paraffin sections using a highly effective CD103 rabbit monoclonal antibody. Am J Clin Pathol 139:220-230

40. Chen YH, Tallman MS, Goolsby C, Peterson L (2006) Immunophenotypic variations in hairy cell leukemia. Am J Clin Pathol 125:251-259

41. Jasionowski TM, Hartung L, Greenwood JH, Perkins SL, Bahler DW (2003) Analysis of CD10+ hairy cell leukemia. Am J Clin Pathol 120:228-235

42. Dong HY, Weisberger J, Liu Z, Tugulea S (2009) Immunophenotypic analysis of CD103+ B-lymphoproliferative disorders: hairy cell leukemia and its mimics. Am J Clin Pathol 131:586-595

43. Falini B, Tiacci E, Liso A, Basso K, Sabattini E, Pacini R, Foa R, Pulsoni A, Dalla Favera R, Pileri S (2004) Simple diagnostic assay for hairy cell leukaemia by immunocytochemical detection of annexin A1 (ANXA1). Lancet 363:1869-1870

44. Tiacci E, Trifonov V, Schiavoni G, Holmes A, Kern W, Martelli MP, Pucciarini A, Bigerna B, Pacini R, Wells VA, Sportoletti P, Pettirossi V, Mannucci R, Elliott O, Liso A, Ambrosetti A, Pulsoni A, Forconi F, Trentin L, Semenzato G, Inghirami G, Capponi M, Di Raimondo F, Patti C, Arcaini L, Musto P, Pileri S, Haferlach C, Schnittger S, Pizzolo G, Foa R, Farinelli L, Haferlach T, Pasqualucci L, Rabadan R, Falini B (2011) BRAF mutations in hairy-cell leukemia. N Engl J Med 364:2305-2315

45. Schnittger S, Bacher U, Haferlach T, Wendland N, Ulke M, Dicker F, Grossmann V, Haferlach C, Kern W (2012) Development and validation of a real-time quantification assay to detect and monitor BRAFV600E mutations in hairy cell leukemia. Blood 119:31513154

46. Andrulis M, Penzel R, Weichert W, von Deimling A, Capper D (2012) Application of a BRAF V600E mutation-specific antibody for the diagnosis of hairy cell leukemia. Am J Surg Pathol 36:17961800

47. Sainati L, Matutes E, Mulligan S, de Oliveira MP, Rani S, Lampert IA, Catovsky D (1990) A variant form of hairy cell leukemia resistant to alpha-interferon: clinical and phenotypic characteristics of 17 patients. Blood 76:157-162

48. Matutes E, Wotherspoon A, Brito-Babapulle V, Catovsky D (2001) The natural history and clinico-pathological features of the variant form of hairy cell leukemia. Leukemia 15:184-186

49. Xi L, Arons E, Navarro W, Calvo KR, Stetler-Stevenson M, Raffeld M, Kreitman RJ (2012) Both variant and IGHV4-34-expressing hairy cell leukemia lack the BRAF V600E mutation. Blood 119:3330-3332
50. Kanellis G, Mollejo M, Montes-Moreno S, Rodriguez-Pinilla SM, Cigudosa JC, Algara P, Montalban C, Matutes E, Wotherspoon A, Piris MA (2010) Splenic diffuse red pulp small B-cell lymphoma: revision of a series of cases reveals characteristic clinico-pathological features. Haematologica 95:1122-1129

51. Traverse-Glehen A, Baseggio L, Bauchu EC, Morel D, Gazzo S, Ffrench M, Verney A, Rolland D, Thieblemont C, Magaud JP, Salles G, Coiffier B, Berger F, Felman P (2008) Splenic red pulp lymphoma with numerous basophilic villous lymphocytes: a distinct clinicopathologic and molecular entity? Blood 111:2253-2260

52. Swerdlow SH, Berger F, Pileri SA, Harris NL, Jaffe ES, Stein H (2008) Lymphoplasmacytic lymphoma. In: Swerdlow SH, Campo E, Harris NL, Jaffe ES, Pileri SA, Stein H, Thiele J, Vardiman JW (eds) WHO Classification of Tumours of the Haematopoietic and Lymphoid Tissues, 4th edn. IARC, Lyon, pp 194-195

53. Treon SP, Xu L, Yang G, Zhou Y, Liu X, Cao Y, Sheehy P, Manning RJ, Patterson CJ, Tripsas C, Arcaini L, Pinkus GS, Rodig SJ, Sohani AR, Harris NL, Laramie JM, Skifter DA, Lincoln SE, Hunter ZR (2012) MYD88 L265P somatic mutation in Waldenstrom's macroglobulinemia. N Engl J Med 367:826-833

54. Morice WG, Rodriguez FJ, Hoyer JD, Kurtin PJ (2005) Diffuse large B-cell lymphoma with distinctive patterns of splenic and bone marrow involvement: clinicopathologic features of two cases. Mod Pathol 18:495-502

55. Kashimura M, Noro M, Akikusa B, Okuhara A, Momose S, Miura I, Kojima M, Tamaru J (2008) Primary splenic diffuse large B-cell lymphoma manifesting in red pulp. Virchows Arch 453:501-509

56. Belhadj K, Reyes F, Farcet JP, Tilly H, Bastard C, Angonin R, Deconinck E, Charlotte F, Leblond V, Labouyrie E, Lederlin P, Emile JF, Delmas-Marsalet B, Arnulf B, Zafrani ES, Gaulard P (2003) Hepatosplenic gammadelta T-cell lymphoma is a rare clinicopathologic entity with poor outcome: report on a series of 21 patients. Blood 102:4261-4269

57. Macon WR, Levy NB, Kurtin PJ, Salhany KE, Elkhalifa MY, Casey TT, Craig FE, Vnencak-Jones CL, Gulley ML, Park JP, Cousar JB (2001) Hepatosplenic alphabeta T-cell lymphomas: a report of 14 cases and comparison with hepatosplenic gammadelta T-cell lymphomas. Am J Surg Pathol 25:285-296

58. Mackey AC, Green L, Liang LC, Dinndorf P, Avigan M (2007) Hepatosplenic $\mathrm{T}$ cell lymphoma associated with infliximab use in young patients treated for inflammatory bowel disease. J Pediatr Gastroenterol Nutr 44:265-267

59. Wu H, Wasik MA, Przybylski G, Finan J, Haynes B, Moore H, Leonard DG, Montone KT, Naji A, Nowell PC, Kamoun M, Tomaszewski JE, Salhany KE (2000) Hepatosplenic gammadelta T-cell lymphoma as a late-onset posttransplant lymphoproliferative disorder in renal transplant recipients. Am J Clin Pathol 113:487-496

60. Hassan R, Franco SA, Stefanoff CG, Romano SO, Diamond HR, Franco LG, Seuanez HN, Zalcberg IR (2006) Hepatosplenic gammadelta T-cell lymphoma following seven malaria infections. Pathol Int 56:668-673

61. Wong KF, Chan JK, Matutes E, McCarthy K, Ng CS, Chan CH, Ma SK (1995) Hepatosplenic gamma delta T-cell lymphoma. A distinctive aggressive lymphoma type. Am J Surg Pathol 19:718-726 